\title{
Business Informatics: An Engineering Perspective on Information Systems
}

\author{
Markus Helfert \\ Dublin City University, Dublin, Ireland
}

Markus.Helfert@dcu.ie

\section{Executive Summary}

Over the last three decades many universities have offered various programmes related to Information Systems. However, the rapid changes in recent years demand constant evaluation and modification of education programmes. Recent challenges include, for instance, the move towards programmes that are more applied and professionally-orientated. The Bologna Declaration in Europe with its three level study structure as well as the increasing pressure to ensure funding within most departments adds further pressure to many universities. Despite attempts being made to provide reference to curricula and guidelines, many universities and faculties struggle with the proper direction and design of the information systems curricula.

Common reference curricula related to information systems are, for example: the IS 2002; Curriculum Guidelines for Undergraduate Degree Programs in information systems; the MSIS 2000: Model Curriculum and Guidelines for Graduate Degree Programs in Information Systems. Although these guidelines have existed for many years, many discussions and disagreements exist on the content and direction of information systems curricula and information systems as a discipline. Recently a joint task force of the Association for Computing Machinery and Association of Information Systems is aiming at revising the IS 2002 undergraduate curriculum (Topi et al., 2007). At the same time we are experiencing decreasing enrolments in information system programmes worldwide (Granger, Dick, Luftman, Slyke, \& Watson, 2007).

This article views information systems study programmes from an engineering perspective and presents a framework for structuring information systems programmes within Europe. We amalgamated the IS 2002 and MSIS 2000 model curriculum with a recommendation for studying business informatics, published from the German Society for Informatics (Gesellschaft für Informatik, 2003). The framework was used to identify differences between selected study programmes currently in place for information systems curricula. For the study we selected two historically different educational systems: the United Kingdom and Ireland as representative for the Anglophone area and Germany, Austria, and Switzerland as representative of a continental European approach.

Material published as part of this publication, either on-line or in print, is copyrighted by the Informing Science Institute. Permission to make digital or paper copy of part or all of these works for personal or classroom use is granted without fee provided that the copies are not made or distributed for profit or commercial advantage AND that copies 1) bear this notice in full and 2) give the full citation on the first page. It is permissible to abstract these works so long as credit is given. To copy in all other cases or to republish or to post on a server or to redistribute to lists requires specific permission and payment of a fee. Contact 0HPublisher@InformingScience.org to request redistribution permission.
We collected data from 20 Universities and classified the studied subject areas along our framework. Our results show that even in the context of the Bologna Declaration and common credit transfer systems, the study programmes nationally and internationally remain very diverse. Indeed, this makes comparisons between study programmes difficult to ascertain. The analysis reveals indications that the controversy in information 
systems is often due to two related but fundamentally diverse streams, one being a technologyand engineering-orientated focus and the other being a business- and management-orientated emphasis. The relatively strong inclusion of engineering principles appears to be typical for business informatics degrees, emphasizing both mathematics and structural science. Logistics, accounting, and economics are specific courses which are common to most business informatics curricula.

The study led to the development and accreditation of a business informatics study programme at Dublin City University. In this article we summarize the curriculum and present experiences made during the accreditation process. Indeed the accreditation process confirmed our earlier result, that information systems have two fundamentally different streams: technology and managerial orientation. This programme was introduced in September 2006, with a relative low number of students enrolling in the programme, and we report on experiences made during the last two years of running the programme. Graduates from this programme were all recruited into related employment. Furthermore, practitioners confirmed the career relevant curriculum. Due to this success, we expect increased attractiveness of the programme. However, the lack of adequate funding to market and promote the degree could impact on the enrollment numbers of the degree.

The final curriculum comprises a balanced and interdisciplinary structure that centers on engineering principles and focuses on transformation, models and methods. The engineering emphasis throughout the programme is seen as one important characteristic. This differentiates the proposed programme from other management oriented information systems degrees. Therefore the business informatics approach appears to us to be innovative with regard to its interdisciplinary character. Furthermore the engineering perspective and the integration of cultural studies and practical experiences in an international setting equip graduates with unique and career oriented capabilities.

The paper concludes that business informatics is not just a new term, but instead offers an engineering oriented stream on information systems. As such, business informatics can complement the traditional managerial oriented study programmes.

Keywords: Business Informatics, Information Systems, Information Management, Curriculum, Study programme, Cultural Differences.

\section{Introduction}

Over the last few decades, universities have offered various courses in management, information technology, computer science, software engineering and more recently information systems, information management, and business informatics. Several of these courses have been established at most universities, and in particular the growth of information technology (IT) and information systems (IS) related programmes are expected to continue. However, recently there are concerns that the number of students registered for information systems related courses could stagnate or fall (Granger et al. 2007). In the United Kingdom (UK) the numbers of students studying information systems dropped from 41,440 students in 2004/05 to 35,765 students in 2005/06 (Higher Education Statistics Agency, 2007), creating significant problems for many information systems departments. While, at the same time, a more applied and professionally orientated computing and information systems education is required and demanded (Denning, 2001).

As the student figures illustrate, the rapid changes in recent years require constant evaluation and modification of education programmes in order to make them attractive and suitable for students. Indeed, claims that Information Technology (IT) is no longer a source of strategic advantage have generated a growing concern over the loss of technology-orientated jobs (Carr, 2003). It will increase the emphasis on 'business-orientated' Information Technology jobs (Benamati \& Mahaney, 2004). 
Generally, it is expected that demand for subjects such as application design and integration, enterprise architecture, information management, and business process management will increase (Traylor, 2003). The demand for graduates capable of coordinating complex information and supply chain networks and project mangers managing global IT projects is also expected to rise (Löwer, 2005). Students may also need to understand how to manage project teams, especially geographically and ethnically diverse teams. On the other hand, innovations in information and software technology should also be considered as key elements of information systems (e.g. Benbasat \& Zmud, 2003; Orlikowski \& Iacono, 2001).

Universities are expected to provide a broad business and real world perspective, strong analytical and critical thinking skills, and interpersonal communication and team skills as well as core knowledge of information systems. These skills should be combined with a solid methodological foundation in design and implementation of information technology solutions that enhance organizational performance (Disterer, Fels \& Hausotter, 2003; Gorgone, Davis, Valacich, Topi, Feinstein \& Longenecker, 2002). Faculties in universities are increasingly under pressure and are expected to offer attractive and profitable study programmes. Schools with traditional computing degree programmes are developing variations in many of their IT programmes (Laundry, Pardue, Longenecker, \& Feinstein, 2003). Business schools are offering various types of management information systems courses and courses with a computing element.

Although attempts have been made to develop frameworks for information systems (e.g. Bacon \& Fitzgerald, 2001) and to provide references for curricula, study programmes are diverse. Common reference curricula related to information systems are for example the $I S$ 2002: Curriculum Guidelines for Undergraduate Degree Programs in Information Systems (Gorgone, Davis, Valacich, Topi, \& Feinstein et al., 2002); the MSIS 2000: Model Curriculum and Guidelines for Graduate Degree Programs in Information Systems (Gorgone et al., 2000). Among faculty, there is often discussion about the direction of IS programmes. Different programmes aim to emphasize selected aspects of information systems (e.g. Benbasat \& Zmud, 2003; DeSanctis, 2003; Galliers, 2003; Klein \& Hirschheim, 2003; Lyytinen \& King, 2004; Orlikowski \& Iacono, 2001; Robey, 2003; Straub, 2003). Discussions among information systems faculty about the core elements and subjects of information systems degrees emerge frequently. In an online discussion in July 2004 on the ISWorld mailing list (www.isworld.org) we counted more than 100 contributions related to programming in the information systems curriculum. In some discussions it seems that the information systems curriculum should include many (if not all) related subjects ranging from business and information system strategy to management and marketing, organizational concepts, modeling and information systems architecture, programming, mathematics, statistics and operations research as well as computing, networking and Information and Communication Technologies (ICT). In addition, the complaints often reported on a regular basis from practitioners are that university educators do not prepare their students adequately for the demands of the real professional career focused world.

In summary, it seems that information systems graduates are expected to be the 'all-in-one person solution suitable for every information systems related problem'. This seems to be symptomatic for the information systems field. Similarly, as Benbasat and Zmud (2003) conclude, a clear identity of the information systems discipline is (still) absent.

Consequently many universities struggle with the proper direction and design of an information systems related curriculum. Aiming to provide guidelines for the faculty in universities, the objective of this article is to evaluate some selected information systems degrees. We choose to compare selected programmes from the Anglophone-European Countries and continental Europe. As representatives we focused on programmes offered in the United Kingdom and Ireland as well as the German-speaking countries Austria, Switzerland, and Germany. For the analysis of our 
study we adapt common reference curricula for information systems and business informatics and propose an analysis framework.

The remainder of this article is structured as follows: Firstly, a brief overview of business informatics as a research and study field will be given. Then we describe the research design and the framework for the comparison of study programmes. This builds the foundation for the third section, which presents the qualitative and consolidated results of our study. In the fourth section we present the application of the framework for developing a study programme in business informatics. The paper concludes with summary and further research directions.

\section{Business Informatics and Information Systems}

Simultaneously with the discussion on key capabilities of IS graduates, there is an ongoing debate regarding the nature and identity of information systems as a discipline. Most of the debate is focused on whether information systems is informed by the business discipline or if it can be rooted in other domains, like healthcare or public administration. Indeed the current model curricula for IS undergraduate studies has clearly identified business as the domain in which IS is located (Gorgone, Feinstein, Longenecker, Topi, Valacich \& Davis, 2002). Although ongoing curricula revision extends this view and recognizes that information systems is a discipline that integrates technology and organizational processes with domain expertise, domain knowledge and business knowledge is still seen as fundamental to the information systems discipline (Topi et al., 2007).

Almost isolated from the broader discussion among the international IS community, a growing number of universities in continental Europe, foremost in German-speaking countries, offer and discuss study programmes in business informatics (Mertens \& Barbian, 2002). In 2006 a panel at the 14th European Conference on Information Systems (ECIS 06) discussed grand challenges in common across Europe concerning education and research in business informatics. The discussion was focused on the importance of core subjects, teaching mode, and research topics within the discipline from a management, information systems, and informatics perspective. The discussion showed that education in information systems is very diverse, with different streams in information systems; on the one hand a technology-, engineering- and method-orientated perspective and on the other hand a business- and management-orientated focus. At the 16th European Conference on Information Systems (ECIS 08) a meeting with academics from various countries was held discussing aspects of business informatics. The discussion emphasized the engineering characteristics of business informatics in contrast to the managerial oriented stream of information systems.

Within the business informatics community, broad agreement exists that business informatics shows numerous similarities to the discipline of information systems; however, there are some particular characteristics that makes business informatics a discipline in its own right. First emerging in the 1970s as a technology-oriented course in business, over the last decade it became an accepted field of research and study. As a stream of information systems, business informatics focuses on business information systems as socio-technical systems comprising both machines and humans (Ferstl \& Sinz, 2001; Heinrich, 2001; Retzer, Fisher, \& Lamp, 2003; Wissenschaftliche Kommission der Wirtschaftsinformatik, 1994).

However, business informatics combines and complements explicitly the domains of informatics and business studies. Informatics is primarily concerned with the technology of information and communication systems, while business studies focuses on management functions. Business informatics aims to support business functions by applying informatics principles and technologies. Business informatics is concerned with the concept, development, implementation, maintenance and utilization of business information systems (Disterer et al., 2003; Scheer, 1998). Business informatics also includes the management of information systems while it emphasizes the rela- 
tionship between humans, business functions, information and communication systems, and technology (Heinrich, 2002). Defined as a science discipline, business informatics is generally categorized as

- applied science that studies real world phenomena,

- formal science that creates and applies formal description methods and models,

- engineering discipline that systematically designs and constructs information and communication systems (Wissenschaftliche Kommission der Wirtschaftsinformatik, 1994).

Therefore business informatics is an interdisciplinary subject (Gesellschaft für Informatik, 2003). It can be summarized as a socio-technological and business oriented subject with engineering penetration (Disterer et al., 2003). In the following section, by comparing selected study programmes, we aim to indicate differences between typical information systems and business informatics programmes.

\section{A Comparison of Study Programmes}

\section{Research Design and Selected Study Programmes}

The objectives of this paper are to evaluate selected information systems degree programmes and provide explanations for the diversity of different streams in the information systems and business informatics domains. For our analyses we selected two historically different educational areas, one in continental Europe and one in the Anglophone region. As representative of a continental European system we selected three countries: Germany, Austria, and Switzerland, all presenting comparable educational structures. On the other hand, we focused on the educational system of the United Kingdom, as it was influential for the educational system of many Anglophone countries. In addition, we decided to include Ireland in the study, not only because of its similar educational system as the UK, but also due to its importance in the computing and software sector with a generally highly regarded educational system. We refer to this educational area in the UK and Ireland as 'UK/Ireland'.

In order to compare the two selected educational areas, hereafter referred to as German-speaking areas and UK/Ireland, we gathered information about the degree programmes using document evaluation. The document evaluation was completed using a four steps procedure:

(1) Firstly, we compiled a list of universities and study programmes to be considered for the study by selecting information systems departments.

Our initial list was completed by a web search for universities offering an information systems related degree. We used a search engine (www.google.com) and the following lists of information systems departments in Europe (retrieved between September 2004 and January 2005):

- Information Systems Departments in Europe (http://juliet.stfx.ca/ rmackinn/infosys/europe.htm)

- Information Systems Departments in the UK (http://www.cs.york.ac.uk/cgibin/ukais.cgi?f=isdepts)

- Information Systems Graduate Schools in the United Kingdom and Ireland (http://www.gradschools.com/listings/UK/info_sys_uk.html)

- UK University Grading and Ranking Systems (http://www.britishhighereducation.com/British_Education/05Grading and Ranking Sys tems.asp)

- List of 'Wirtschaftsinformatik' study programmes in Germany (http://www.studienwahl.de/) 
- Ranking of Intuitions that published in the journal 'Wirtschaftsinformatik' (Resch \& Schlögl, 2004).

The search resulted in an extensive list of universities and IS degree programmes. By aiming to identify the most relevant study programmes, we subsequently reduced the list to a set of universities. We used the above-mentioned ranking information (qualitative analyzed by domain experts). In addition we consulted 10 Professors and Lecturers from different European countries teaching information systems, asking about their subjective ranking of the relevance of degree programmes. We combined the results and finalized a lists of universities considered for the further study (The list is presented in Appendix A).

(2) In the second step we developed an evaluation framework, which was refined to run in conjunction with step 3 .

(3) Thirdly, detailed descriptions of the study programmes were collected and a comprehensive list of taught subjects compiled (This list is presented in Appendix B and Appendix C).

(4) Finally, the taught subjects are assigned to the categories within the framework and qualitatively analyzed.

As our study intends to provide indications and directions of different streams in IS, we did not aim to provide a full and comprehensive list of universities offering information systems-related courses. The empirical study was completed between September 2004 and September 2005, and is based on electronically available documents of study programmes at that time. Where further course information was unavailable on the university's web page we excluded the study programmes from the detailed analysis.

\section{IS Evaluation Framework}

In order to develop an evaluation framework, we amalgamated prominent curriculum guidelines; an undergraduate and a graduate model curriculum predominantly referred to in the Anglophone area with one frequently referred reference curriculum in the German-speaking area:

- the model curriculum and guidelines for graduate degree programmes in information systems (MSIS 2000) (Gorgone et al., 2000),

- the most recent version of the information systems undergraduate model curriculum (IS 2002) (Gorgone \& Davis et al., 2002) and

- the recommendation for business informatics at universities (BI recommendation) (Gesellschaft für Informatik, 2003).

The work of IS model curricula represent almost 30 years of experience in curriculum development. Started in the early 1970s by the Association for Computing Machinery (ACM) other organizations, including DPMA/AITP (Data Processing Management Association/Association of Information Technology Professionals), IFIP (International Federation for Information Processing) and AIS (Association for Information Systems), have aided model curriculum development. The IS 2002 model curriculum is the most recent version for an undergraduate IS curriculum, published by the ACM and AIS. IS 2002 includes detailed course descriptions and prescriptive advice on how to offer an IS undergraduate degree programme. For our study we used the most recent version of the IS 2002 undergraduate curriculum, although the current version is currently under review by a joint ACM/AIS task force (Topi et al. 2007). The MSIS 2000 model curriculum was published by ACM and AIS as a guideline for master degree programs in information systems. On a masters level, the curriculum is designed to accommodate students from a wide variety of backgrounds. It considers a set of interrelated building blocks including foundational 
skills, core subjects, integration subjects, and career tracks. Emphasizing on career development skills, the curriculum includes: oral, written, and presentation skills; people and business skills; ethics and professionalism.

The model curricula are explicitly developed to include knowledge elements from three major computing disciplines: computer science, software engineering, and information systems. It accumulates long experience in IS curriculum development and provides a coherent structure for a study programme in information systems. Thus these model curricula seem to be appropriate, even though the model curricula are primarily based on the educational system and degree structures common to the USA and Canada, with limited acceptance and use outside of this area. The two level educational structures underlying the curricula proved to be of advantage, as many European universities are restructuring their study programmes towards a 2-phase curriculum with Bachelor and Master Degrees.

The third curricula we used, the recommendation for business informatics (BI), is issued by the German Society for Informatics and the Association of University Professors of Management, Germany. It is aimed at providing common directions for education in business informatics at universities. In contrast to the MSIS curriculum, which provides a detailed recommendation for a curriculum, the BI recommendation is intended as a guideline and is focused on key qualifications and core subjects to be taught. The BI recommendation is mainly orientated on a study programme of nine semesters leading to a degree of 'Diplom-Wirtschaftsinformatik' (Diploma/Master Level in business informatics).

In order to cluster subjects and to match the consolidated list of taught subjects, we customized the initial framework in an iterative process involving expert opinion from 10 academics from different countries. In addition, the framework was also discussed at international conferences (e.g. Helfert 2007; Helfert \& Duncan, 2006, 2007). The structure follows the proposed curriculum building blocks in the MSIS curriculum. However, in order to accommodate particular subjects taught in some study programmes, we added subject blocks of mathematics and logic, structural science, legislation, and economics, and business engineering (Winter, 2002), and included often taught business subjects, for example logistics, procurement, and supply chain management. The list of career electives and domain specific subjects presented here illustrates just some of the possible topics. The final framework is presented in Table 1.

\section{Qualitative and Consolidated Results}

For our study we compiled a list of different subjects taught in the selected degree programmes. However, due to the large number of subjects, a further classification was necessary in order to identify differences between the degrees. Applying the framework above, we assigned particular courses to our categories in the framework. The qualitative results are presented along with characteristics of the terminology used, content, structure and legal framework as well as credit system. 
Table 1: Framework for information systems study programmes

\begin{tabular}{|c|c|c|c|c|}
\hline $\begin{array}{l}\text { Fundamentals in } \\
\text { Informatics }\end{array}$ & $\begin{array}{l}\text { Business and } \\
\text { Economics }\end{array}$ & Information Systems & $\begin{array}{l}\text { Integration and } \\
\text { Enterprise } \\
\text { Engineering }\end{array}$ & $\begin{array}{l}\text { Domain-specific career } \\
\text { electives (representative) }\end{array}$ \\
\hline $\begin{array}{l}\text { Information and } \\
\text { Communication } \\
\text { Technology (Hard- } \\
\text { ware, Software, } \\
\text { Networks and } \\
\text { Communication } \\
\text { Technology) } \\
\text { Programming and } \\
\text { Algorithms, Data } \\
\text { and Object Struc- } \\
\text { tures } \\
\text { Mathematics and } \\
\text { Logic (Analysis, } \\
\text { linear Algebra, } \\
\text { Numeric, Logic) } \\
\text { Structural Science } \\
\text { (Decision theory } \\
\text { and methods for } \\
\text { strategic decision } \\
\text { making (e.g. risk } \\
\text { analysis), statistics } \\
\text { and quantitative } \\
\text { models and meth- } \\
\text { ods, operations } \\
\text { research, computa- } \\
\text { tional modeling and } \\
\text { simulation) }\end{array}$ & $\begin{array}{l}\text { Accounting and } \\
\text { Financing } \\
\text { Marketing, Produc- } \\
\text { tion, Procurement, } \\
\text { Logistics, Supply } \\
\text { Chain Management } \\
\text { Organization, } \\
\text { human resources } \\
\text { and corporate } \\
\text { management } \\
\text { Legislation and } \\
\text { Economics }\end{array}$ & $\begin{array}{l}\text { Fundamentals of Informa- } \\
\text { tion Systems (Types of IS, } \\
\text { IS Industry, IS relevant } \\
\text { legal frameworks, Man- } \\
\text { agement and IS) } \\
\text { Principles of Business In- } \\
\text { formation Systems (Princi- } \\
\text { ples of functional and proc- } \\
\text { ess orientation and industry } \\
\text { solutions) } \\
\text { Data Engineering (Data } \\
\text { modeling and management, } \\
\text { knowledge engineering and } \\
\text { business intelligence) } \\
\text { System and Software Engi- } \\
\text { neering (analysis, modeling } \\
\text { and design) } \\
\text { Managing Data Communi- } \\
\text { cation and Networking } \\
\text { Information Management } \\
\text { (Information, Knowledge } \\
\text { and People, Project and } \\
\text { Change Management, IS/IT } \\
\text { Policy and Strategy, Ethics } \\
\text { and Privacy) }\end{array}$ & $\begin{array}{l}\text { Business Engineer- } \\
\text { ing and Information } \\
\text { System Architecture } \\
\text { Integrating Infor- } \\
\text { mation System } \\
\text { Functions, Proc- } \\
\text { esses and Data } \\
\text { Integrating Infor- } \\
\text { mation System } \\
\text { Technologies and } \\
\text { Systems }\end{array}$ & $\begin{array}{l}\text { Academia and Research } \\
\text { Biochemistry and Mo- } \\
\text { lecular Biology } \\
\text { Consulting } \\
\text { Consumer Health Infor- } \\
\text { mation } \\
\text { Customer Relationship } \\
\text { Management } \\
\text { Data Warehousing } \\
\text { Decision Making } \\
\text { E-Government } \\
\text { Electronic Commerce } \\
\text { Electronic Publishing } \\
\text { Environmental manage- } \\
\text { ment } \\
\text { Financing and Banking } \\
\text { Healthcare Information } \\
\text { Human Factors } \\
\text { Insurance Management } \\
\text { Knowledge Management } \\
\text { Library Services } \\
\text { Multimedia Technologies } \\
\text { Research Libraries } \\
\text { Techniques of IT- } \\
\text { consulting } \\
\text { Technology Management }\end{array}$ \\
\hline
\end{tabular}

\section{Terminology}

The term 'business informatics' (in German: 'Wirtschaftsinformatik') is widely accepted in business and academia in the German-speaking countries (nearly all degree programmes are labeled as 'business informatics'). In the UK/Ireland the term information systems or information management is often used. Table 2 illustrates some further examples of masters level degree programmes and the terminology used in the UK/Ireland.

Table 2: Overview of Terminologies used for study programmes in the UK/Ireland

\begin{tabular}{|l|}
\hline MSc Analysis, Design and Management of Information Systems \\
MSc Business Administration (IT) \\
MSc in Advanced Computer Science with ICT Management \\
MSc in Information Management \\
MSc in Multidisciplinary Informatics \\
MSc Information and Knowledge Management \\
MSc Information Systems \\
MSc in Electronic Commerce (Technical and Business) \\
\hline
\end{tabular}

\section{Content}

In order to provide an indication of key subjects, we identified some indicators by summarizing typical study profiles (Although the number of study programmes involved does not allow a detailed quantitative analysis). In contrast to information systems, business informatics appears to have a stronger focus on mathematics, logic, and structural science, which includes statistics and operations research. One reason for this could be the focus on the systematic construction and the 
application of methodological principles, which are often stated as typical for business informatics (Disterer et al., 2003; Gesellschaft für Informatik, 2003; Heinrich, 2002; Retzer et al., 2003). In this regard business informaticians are often described as information system architects (in the sense of engineers) who are actively and systematically analyzing and designing business information systems. Indeed, in general, mathematical principles are perceived as essential in order to systematically construct, formalize, and analyze models and architectures of information systems (Henderson, 2003).

It is also interesting to note that universities in both the UK/Ireland and the German-speaking countries regard systems and software engineering courses as important. This might be an interesting differentiator to programmes in North America. Another indication of the importance of programming in the study programme might be indicated by the proportion of information and communication technology, programming and algorithms, data and object structures courses in both UK/Ireland and the German-speaking regions. In addition, most UK/Ireland based degrees include a substantial course in data engineering.

Study programmes in the UK/Ireland have generally a more open study structure. They are often designed as conversion programmes, which require no particular knowledge in management or informatics or accept students from various backgrounds. Within conversion programmes, fundamentals of information systems are given more weight in contrast to the more specific courses on business information systems in the German-speaking area. This specialization in business subjects might be justified by considering the comparatively long study duration of nine semesters and the design as integrated curriculum (even over two levels of Bachelor and Master). Degrees in the UK/Ireland are mostly designed as one-year programmes.

Another interesting observation is the stronger focus on information management in UK/Ireland. The courses focus more on the alignment of business strategies and information technology (e.g. courses in information systems strategy) as well as the management of information technology and technology-orientated teams. In addition, the UK/Ireland based courses tend to have a high proportion of career electives, which might indicate the character of masters level degrees as a means of specialization beyond the undergraduate level. In contrast, courses in the Germanspeaking countries appear to have more detailed courses in business. The majority of business informatics degrees in the German-speaking countries offer particular and substantial courses in accounting, finance, and logistics (or supply chain management) and include a course in economics.

\section{Structure and legal framework}

Despite the Bologna Declaration, with an agreement among European countries for a common educational area with a three level study structure, the degree structure in different countries is still very different (General reports regarding the current status of the higher education area of each European Union member state can be found at Ministry of Education and Research, 2005). Some of the differences in study programmes might be attributed to the lack of a comprehensive framework of qualifications and requirements. This is notable, as since the identification of a three cycle structure within the Bologna Declaration, a need for developing an over-arching qualifications framework for the European Higher Education Area (EHEA) was identified (Bologna Working Group on Qualifications Frameworks, 2005). At present only a few European countries have developed comprehensive qualification frameworks; an accepted common European Framework is still some way off.

In the context of the Bologna process, Germany for instance adopted in 2005 the 'Qualifications Framework for German Higher Education Degrees', recognizing explicitly Bachelors, Masters and Doctorate. This presented a major and time-consuming process, as in Germany the commu- 
nity of 'Länder' (states) is responsible for the educational system. The degree accreditation is a procedure of external quality assurance based on the principle of peer review, carried out by local agencies. The local agencies themselves are accredited by the German Accreditation Council, which ensures the basic requirements for the accreditation procedure.

In contrast, the UK and Irish degree system has long tradition of three main cycles (Bachelors, Masters, and Doctorate). Universities in both countries are, compared to many continental European countries, relatively autonomous. They usually have full autonomy to award their own degrees and qualifications. Similarly, the quality assurance system in the UK and Ireland has a longer tradition. For instance, the quality assurance activities in the UK are concentrated at the Quality Assurance Agency (QAA), which outlines quality assurance principles, policies, and audit and review processes. In addition, in the UK the British Computer Society develops and maintains standards in educational qualifications in computing or information systems. Currently approximately 60 higher education courses in the UK are accredited by the British Computer Society, however mostly on a bachelor level.

Owing to the different traditions and legal frameworks, differences in the present educational structure and the implementation of the Bologna Declaration can be expected. The Germanspeaking regions typically offer an integrated degree of 8-9 semesters. In the last few years some universities have changed to awarding separate degrees of Bachelor and Masters levels. However the formal bachelor and master level studies are still mostly structured as an integrated programme. It is designed so that graduates from a Bachelor degree continue on to the Master level, often at the same university. In the UK/Ireland, the Bachelor and Master programmes are designed as conversion courses that are more decoupled. These programmes allow more flexibility in changing universities and study focus. In contrast, universities in the German-speaking regions mostly assume that students at the master level have the same knowledge as the bachelor graduates from their own study programme.

In the German-speaking areas business informatics courses in general (still) lead to a Diploma after five years of study. The equivalent qualification in the UK/Ireland is a masters degree. In UK/Ireland the Masters level courses, offered in a number of universities, fall into two kinds 'conversion' courses and 'add-on' courses. The conversion courses are offered to graduates in disciplines other than computing, and aim to provide a competence in computing disciplines and the business applications of information technology. They do not provide a deep study of either discipline, nor of information system engineering aspects. The add-on courses are typically offered to graduates in computer science and offer an understanding of information management and the place of IT in business processes. Some of them offer advanced courses on business studies, information management and information strategy.

\section{Credit system}

With the implementation of the Bologna Declaration, the European Credit Transfer and Accumulation System (ECTS) was promoted across the European Union. ECTS offers a standard for comparing the study attainment and performance of students across higher education institutions. Introduced in 1989 within the framework of Erasmus, ECTS was set up initially as a credit transfer system, in order to facilitate student mobility. Recently ECTS is developing into a credit ac-

cumulation system. ECTS is a student-centered system based on the student workload required to achieve the objectives of a programme. It is based on the student workload of a full-time study programme in Europe, estimated to around 1500-1800 hours per year. With a one year programme of corresponding 60 ECTS credits, in most cases one credit stands for around 25 to 30 working hours. 
Most universities in the German-speaking area provide information about ECTS credits (BMBF 2008). In addition the study effort of courses is often converted to the traditional measure of 'lecturing hours per week per semester'. Typically one hour of lecturing per week is translated to 1.5 ECTS credits. A 'Diploma' degree, which is still the norm, involves about nine semesters of study with about 250 to 270 ECTS. This includes a Master-Diploma thesis of 40-60 ECTS. The thesis takes between 4-6 months.

In Ireland, following the establishment of the Irish National Framework of Qualification, institutions are using ECTS conventions, with a Taught Masters Degree amounting between 60-120 ECTS. This includes a major research project of 30-60 ECTS credits.

While many UK universities and colleges have for many years been using credit accumulation within their institutions, the UK uses mostly the Credit Accumulation Transfer Scheme (CATS). In contrast to ECTS, which is based on workload, CATS is based on study outcomes. At operational level general agreement exists that one ECTS credit is equivalent to two CATS credits. In the UK most universities require 160-180 CATS for a one-year Master programme. The Master thesis takes approximately 4 months and accounts for between 40-90 CATS. The formal conversion between ECTS and CATS is helpful to compare study programmes, however has important consequences for postgraduate courses and the amount of study a student is expected to achieve.

\section{A Study Programme in Business informatics}

\section{Rational and Accreditation for the New Programme}

Aiming to complement the traditional portfolio of study programmes in computing, software engineering, and information systems, Dublin City University decided in 2004 to use the findings of the study above for the introduction of a new Masters degree in business informatics. The overall aim of the programme is to expand the knowledge students gain in a primary degree of computer science or software engineering and provide the students with an understanding of business informatics. We aim to offer the students a professional oriented skill-set, enabling them to analyze business problems and develop information systems solutions. In particular following objectives for the course were set:

- The course will equip students to analyze business problems from both technological opportunities and business requirements.

- The course will equip students to develop solutions to business problems using ICT to its full potential.

- Students will learn methodologies that enable a clear understanding of business problems and the function of ICT in business.

- Students will understand constraints, both organisational and technological in designing information system solutions.

- Students will be provided experience in working in an inter-cultural work environment.

The programme was developed and introduced over two years, with a first intake of students in September 2006. As described above, degree programmes at Irish universities can be accredited autonomously by the university but also require external peer review. The accreditation process took place between the first proposal for the programme in 2004 and the final recommendation for accreditation in May 2005. Four external experts in the field of business informatics from Ireland, UK, and Austria were invited to peer review the programme. Representing the interdisciplinary character of the programme, we intended to include members from different backgrounds 
representing a thematically well-balanced accreditation board. Members of the board presented particular expertise in

- Knowledge and Data Engineering and Process Modeling

- Strategic Information Systems

- Information Systems Management

- Practical experience in the banking sector

The accreditation board met and discussed the curriculum three times during the process. The diversity of particular expertise was reflected within the discussions and recommendations. Based on the recommendations, several changes and revisions for the programme were included. The diversity of different viewpoints, reflected in the recommendations, made it difficult to maintain the characteristics of business informatics throughout the programme. It seems the curriculum should include many related subjects ranging from business and information system strategy to mathematics, statistics, and programming. However, due to the limitation placed on workload (90 ECTS), we had to prioritize, balance, and even exclude subjects.

\section{Programme Layout}

The central focus of the curriculum for business informatics is to educate individuals to plan and lead IS-related projects, both technological and organisational. The core aim is enabling students to apply technological solutions and develop information systems architectures to solve business problems of organizations. With this goal in mind the curriculum focuses on an engineering and methodology perspective. Intended intakes for the programme are students who have achieved a primary degree in computing, computer science, software engineering, or a comparable discipline. Furthermore, the objective was to integrate inter-cultural work experiences into the programme. The programme is designed to be completed in one calendar year of full-time study, with 90 ECTS workload. It consists of two taught semesters followed by a practical project in the third semester over the summer months.

\section{Curriculum structure}

Throughout the curriculum we emphasize engineering principles. We include a module in structural science, which encompasses management science, data engineering, and data mining. The curriculum also has a strong modelling component and includes modules in IS architecture and business process management. An additional business perspective is provided by a module in supply chain management. The programme also covers the more traditional information systems disciplines, for instance in the strategic management of information technology module. An overview of the general programme structure is provided in Table 3 . We organize the subjects along three complementary strands: business and consulting skills, information technology / information systems in business, and informatics in action. 
Table 3: Curriculum Overview

\begin{tabular}{|c|c|c|}
\hline Term & \multicolumn{2}{|c|}{ Subjects and Courses } \\
\hline Semester 1 & $\begin{array}{l}\text { - } \text { Research Skills / Seminar Topics }{ }^{1} \\
\text { - Information System Architecture } \\
\text { - } \text { Structural Science }^{2}\end{array}$ & $\begin{array}{l}\text { - } \text { Business Process Management }^{2} \\
\text { - } \quad \text { Strategic Management of Information Tech- } \\
\text { nology }^{2} \\
\text { - } \quad \text { Business Studies } \\
\end{array}$ \\
\hline Semester 2 & 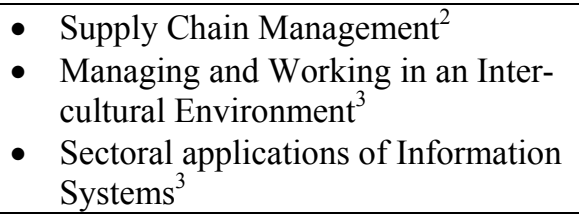 & $\begin{array}{l}\text { - } \text { Regulation in Information Systems }^{2} \\
\text { - } \text { Project Management }^{1} \\
\text { - } \text { Managing Change }^{3}\end{array}$ \\
\hline Summer & - Dissertation (major Project of practic & 1 nature $)^{3}$ \\
\hline
\end{tabular}

1) Business and Consulting Skills

2) Information Technology / Information Systems in Business

3) Informatics in Action

\section{Consideration of transferable skills}

A major goal of this program is to prepare students for their future career in business informatics, either in academia or in practice. However, because the work environment is changing rapidly, few students will have a 'job for life'. Graduates will have to be adaptable and be willing to become 'lifelong learners'. For this reason, in addition to the strong knowledge in business informatics, the programme aims to enhance key transferable skills. This will enable the graduates to take on a variety of jobs in various types of organisations. Transferable skills are those skills which, having been learned in one context, can then be applied in another. Students in this course are expected to already have well-developed key skills, mainly from their earlier education and possibly from their work experience. However, we included programme features, teaching, and assessment methods aiming to expand transferable skills. The curriculum and module descriptors include:

- guided independent study and activity, with specialist input when appropriate

- recent or current case studies

- essay and report writing

- collaborative group work and discussions

- presentation of findings to the group as a whole

- intercultural work experience

A summary of transferable skills by module is provided in Appendix D. Over the last two years of running the programme, the importance of these transferable skills was confirmed by employers and feedback from students graduating in this course. The skill set provided noticeably increased career opportunities, with all graduates finding employment after graduation.

\section{Master project of practical nature}

In the final term of study, from June to September, students work on a major project of a practical nature. The general objective of the practicum is to allow students to draw on the theoretical knowledge gained over the taught element and to apply it in a practical setting in a European environment. The practicum gives students the opportunity to demonstrate their ability to analyze problems in the field of business informatics and draw conclusions according to scientific methods within a given timeframe (4 months). From the two cohorts of students studying the course to date, most students selected a practical oriented topic. Although practical oriented, the project is not a placement but rather a research project of a practical nature. Recent topics include: 
- An Implementation Framework for open source Enterprise Resource Planning systems adoption within Small to Medium Sized Enterprises

- Information Technology Support for Detecting Money Laundering Activities

- Penetration of Open Source Supply Chain Technologies in German Small Medium Sized Enterprises

- Service Oriented Architecture in Supply Chain Management - How service orientation affects supply chain performance

- Analysis of the factors that contribute to the success of Business Process Re-Engineering within the Irish Health Care Industry

- Conceptual Model for Handling Complex Administrative Processes

In order to experience working in an intercultural setting, students complete this project at one of our partner universities in a different country. The project is supervised by both a supervisor at the host university as well as from Dublin City University. The arrangement of the term abroad is a significant administrative task, however extremely valuable for the students' skills development and experiences.

\section{Experiences Gained and Conclusion}

This article presented a framework for structuring information systems study programmes in Europe. Based on this framework we studied and illustrated differences between selected study programmes in information systems in the UK, Ireland and Austria, Switzerland, and Germany. Our results show that even in the context of the Bologna Declaration in Europe with broad agreement of a common educational area, the study programmes, nationally and internationally, are still very diverse and difficult to compare. In particular, for historical and legislative reasons, programmes in the German-speaking countries show a close integration between bachelor and master levels. In the UK/Ireland the dependencies between bachelor and master level are more decoupled. Another result of our study illustrates that the term 'business informatics' is commonly used and accepted in the German-speaking regions. In the UK/Ireland different terminologies are used, although terms like information systems or information management are frequent.

One of our main observations of this study is the relatively strong emphasis on engineering principles in typical business informatics degrees, including mathematics and structural science. In addition logistics, accounting, and economics as specific courses are part of most business informatics curricula. However, the sometimes-claimed stronger emphasis on aspects of integration in business informatics degrees and the particular holistic character of business informatics (Disterer et al., 2003; Mertens, 1998; Scheer, 1998) could not be observed in the selected study programmes.

The study led to the development of a business informatics study programme at Dublin City University, Ireland. The analysis showed that the common study programmes in information systems emphasize the managerial aspects, and business informatics provides a complementary stream to these study programmes. Furthermore, business informatics offers many characteristics identified from practitioners as important. The proposed framework helped us to identify different subject areas in information systems, and we identified areas that we expect students have gained through their primary degree. Subsequently, we would be able to classify topics students should acquire during the masters programme. Furthermore, we could compare our business informatics degree with other information systems degrees.

We summarized the curriculum and presented experiences made during the accreditation process. The final curriculum as outlined in Table 3 comprises a balanced and interdisciplinary structure, which centered on engineering principles and focuses on transformation, models and methods. 
The engineering penetration throughout the programme is seen as one important characteristic, which differentiates this programme from management oriented information systems degrees. Therefore the business informatics approach appears to us not only to be innovative with regard to its interdisciplinary character, but moreover the engineering perspective and the integration of cultural studies and practical experiences in an international setting equip graduates with required capabilities.

The masters programme was launched in September 2006, and further evaluation and adjustments of the curriculum may be required in the future. In 2007 we graduated the first cohort of students. All graduates found roles as information system analyst, business analyst, or IT consultant in various sectors, such as financial service industry, logistics, software industry, and the public sector. The excellent career opportunities of the graduates made the programme more attractive for students. However, the successful establishment of new study programmes needs time and resources in terms of marketing and promotion. Because of financial restrictions marketing and promotion was identified as a main weakness in making the programme more attractive. For the third year of offering this programme, we expect a large increase in enrollment in the programme, with an increasing demand in the future.

In our further research we intend to analyze the differences to other information systems programmes. Also our work provides the foundation for a comprehensive analysis of European study programmes. This is part of the Erasmus-funded curriculum project BIN-Net: business informatics Network in Common Europe. It has been funded under Erasmus project within the Socrates Programme.

The emphasis on engineering principles, in addition to the subjects of business, informatics, and information systems should facilitate an analytical and integrated approach. Indeed, the focus on engineering principles in business informatics can play an important role in future education programmes. In this context, business informatics can complement the management-orientated stream of an information systems discipline, which often focuses on the business and management aspects. Both business informatics and management-oriented information systems courses are important and complement each other.

\section{References}

Bacon, J., \& Fitzgerald, B. (2001). A systemic framework for the field of information systems. Data Base, $32(2), 46-67$.

Benamati, S., \& Mahaney, R. (2004). The future job market for information system graduates. Proceedings of the Tenth Americas Conference on Information Systems, New York, pp. 2925-2928.

Benbasat, I., \& Zmud, R.W. (2003). The identity crisis within the IS discipline: Defining and communicating the discipline core properties. MIS Quarterly, 27(2), 183-194.

BMBF - Bundesministerium fuer Bildung und Forschung. (2008). Bologna Process: 2005 to 2007 National report for Germany and national action plan for recognition of foreign qualifications by KMK and $B M B F$, Bundesministerium fuer Bildung und Forschung. Retrieved January 2008 from http://www.ond.vlaanderen.be/hogeronderwijs/bologna/links/National-reports2007/National_Report_Germany2007.pdf

Bologna Working Group on Qualifications Frameworks. (2005). A framework for qualifications of the European higher education area. Copenhagen: Ministry of Science, Technology and Innovation. Retrieved from http://www.bologna-bergen2005.no/Docs/00-Main_doc/050218_QF_EHEA.pdf

Carr, N. G. (2003). IT doesn't matter. Harvard Business Review, 81(5), 41-49.

Denning, P. (2001). The IT schools movements. Communication of the ACM, 44(8), 19-22. 


\section{Business Informatics}

DeSanctis, G. (2003). The social life of information systems research: A response to Benbasat and Zmud's call for returning to the IT artifact. Journal of the Association for Information Systems, 4(7), 360-376.

Disterer, G., Fels, F., \& Hausotter, A. (Eds). (2003). Taschenbuch der wirtschaftsinformatik [Paperback of business informatics] (2nd ed.). Carl Hanser Verlag, München Wien.

Ferstl, O.K., Sinz, E.J. (2001). Grundlagen der wirtschaftsinformatik [Fundamentals of business informatics] (4th ed.). München, Wien: Oldenbourg.

Galliers, R. (2003). Change as crisis or growth? Toward a trans-disciplinary view of information systems as a field of study: A response to Benbasat and Zmud's call for returning to the IT artifact. Journal of the Association for Information Systems, 4(6), 337-351.

Gesellschaft für Informatik (Ed.). (2003). Rahmenempfehlung für die universitätsausbildung in wirtschaftsinformatik [Guidelines for the education in business informatics at universities]. Informatik Spektrum 26(2), 108-113.

Granger, M., Dick, G., Luftman, J., Slyke, C., \& Watson, R. (2007). Information systems enrollments: Can they be increased? Communication of the Association for Information Systems, 20(41), 649-659.

Gorgone, J., Gray, P., Feinstein, D.L., Kasper, G.M., Luftman, J., Stohr, E.A., et al. (2000). Model curriculum and guidelines for graduate degree programs in information systems. Communication of the Association for Information Systems, 3(1), 1-51.

Gorgone, J., Davis, G., Valacich, J., Topi H., Feinstein, D., \& Longenecker, H. (2002). IS 2002: Model curriculum and guidelines for undergraduate degree programs in information systems. Association for Information Systems.

Gorgone, J., Feinstein, D., Longenecker, H. E., Topi, H. Valacich, J. S., \& Davis, G. B. (2002). Undergraduate information systems model curriculum update - IS 2002. Proceedings of the Eighth Americas Conference on Information Systems.

Heinrich, L. J. (2001). Wirtschaftsinformatik - Einführung und grundlegung [Business informatics - Introduction and foundation] (2nd ed.). München, Wien: Oldenbourg.

Heinrich, L. J. (2002). Informationsmanagement - Planung, Überwachung und Steuerung der Informationsinfrastrukutr [Information management - Planning, monitoring and management of information infrastructure] (7th ed.). München, Wien: Oldenbourg.

Helfert, M. (2007). Teaching information quality skills in a business informatics programme. Proceedings of the MIT Information Quality Industry Symposium, Cambridge, Massachusetts, USA, 908-912.

Helfert, M., \& Duncan, H. (2006). Aspects on information systems curriculum: A study program in business informatics. In B. Donnellan, T. Larsen, L. Levine, \& J. DeGross (Eds.), International Federation for Information Processing (IFIP), Volume 206, The transfer and diffusion of information technology for organizational resilience (pp. 229-237). Boston: Springer.

Helfert, M., \& Duncan, H. (2007). Evaluating information systems and business informatics curriculum. Proceedings of International Conference on Computer Systems and Technologies - CompSysTech'07, University of Rousse, Bulgaria.

Henderson, P. (2003). Mathematical reasoning in software engineering education. Communications of the $A C M, 46(9), 45-50$.

Higher Education Statistics Agency. (2007). Students and qualifiers data tables. Retrieved August 4, 2007 from http://www.hesa.ac.uk/index.php?option=com_datatables\&Itemid=121

Klein, H., \& Hirschheim, R. (2003). Crisis in the IS field? A critical reflection on the state of the discipline. Journal of the Association for Information Systems, 4(5), 237-293.

Laundry, J. P., Pardue, J. H., Longenecker, H. E., \& Feinstein, D. F. (2003). A common theme for IT degree programs. Communications of the ACM, 46(11), 117-120. 
Löwer, Ch. (2005). Der Methusalem-Effect [The Methuselah-Effect]. Spiegel Special - Das Magazin zum Thema 'Student 2005', 1, 100-103.

Lyytinen, K., \& King, J. (2004). Nothing at the center? Academic legitimacy in the information systems field. Journal of the Association for Information Systems, 5(6), 220-246.

Mertens, P. (1998). Geschichte und ausgewählte gegenwartsprobleme der wirtschaftsinformatik [History and selected current problems of business informatics]. WiSt Wirtschaftswissenschaftliches Studium, 27(4), 170-175.

Mertens, P., \& Barbian, D. (2002). Zur situation der wirtschaftsinformatik im lichte des studienführers [The situation of business informatics in the view of the study guide]. Wirtschaftsinformatik, 44(5). 502505.

Ministry of Education and Research. (2005). National reports 2005. Retrieved January 152005 from http://www.bologna-bergen2005.no/en/national_impl/05Nat_rep.htm

Orlikowski, W., \& Iacono, C. (2001). Desperately seeking the 'IT' in IT research - A call to theorizing the IT artifact. Information Systems Research, 12(2), 121-134.

Resch, A., Schlögl, Ch. (2004). Die wirtschaftsinformatik aus der sicht ihres hauptpublikationsorgans Eine szientometrische analyse der zeitschrift wirtschaftsinformatik / angewandte Informatik [Business informatics from the perspective of its main publication organ - A scientometric analysis of the journal business informatics / applied informatics].Wirtschaftsinformatik, 46 (4), 302-310.

Retzer, S., Fisher, J., \& Lamp, J. (2003). Information systems and business informatics: An Australian German comparison. Proceedings of the 14th Australian Conference on Information Systems.

Robey, D. (2003). Identity, legitimacy and the dominant research paradigm: An alternative prescription for the IS discipline: A response to Benbasat and Zmud's call for returning to the IT artifact. Journal of the Association for Information Systems, 4(7), 352-359.

Scheer, A.-W. (1998). Wirtschaftsinformatik- Referenzmodelle für industrielle geschäftsprozesse [Business informatics - Reference models for industrial business processes] (2nd ed.). Berlin: Springer.

Straub, D. (2003). IS research perspectives: A mandate for scholarly debate. Journal of the Association for Information Systems, 4(5), 233-236.

Traylor, P. S. (2003). Outsourcing. CFO, 19(15), 24.

Topi, H., Valacich, J., Kaiser, K., Nunamaker, J., Sipior, J., Vreede, G., \& Wright, R. (2007). Revisiting the IS model curriculum: Rethinking the approach and the process. Communications of the Association for Information Systems, 20(11), 728-740.

Winter, R. (2002). An executive MBA program in business engineering: A curriculum focusing on change. Journal of Information Technology Education, 1(4), 279-288. Retrieved from http://jite.org/documents/Vol1/v1n4p279-288.pdf

Wissenschaftliche Kommission der Wirtschaftsinformatik. (1994). Profil der wirtschaftsinformatik [The profile of business informatics]. Wirtschaftsinformatik, 36(1), 80-81. 


\section{Appendices}

\section{Appendix A: List of Universities}

\begin{tabular}{|c|c|c|}
\hline University & $\begin{array}{l}\text { Leading Faculty / } \\
\text { Department }\end{array}$ & URL \\
\hline University Bamberg & $\begin{array}{l}\text { Business informatics and } \\
\text { Applied Informatics }\end{array}$ & http://www.uni-bamberg.de/wiai/ \\
\hline $\begin{array}{l}\text { University Duisburg- } \\
\text { Essen }\end{array}$ & Business & $\begin{array}{l}\text { http://cms.uni-duisburg- } \\
\text { essen.de/studienangebote/studienangebote 06640.shtml }\end{array}$ \\
\hline $\begin{array}{l}\text { University Erlangen- } \\
\text { Nürnberg }\end{array}$ & $\begin{array}{l}\text { Business Administration, } \\
\text { Economics and Social } \\
\text { Science \& Engineering } \\
\text { Sciences }\end{array}$ & http://www.wi2.uni-erlangen.de \\
\hline University Linz & Information Engineering & http://www.winie.uni-linz.ac.at/ \\
\hline University Mannheim & Business \& Informatics & http://www.bwl.uni-mannheim.de/Fakultaet/60/de/index.html \\
\hline University Münster & business informatics & http://www.wiwi.uni-muenster.de/fakultaet/organisation/wi.html \\
\hline $\begin{array}{l}\text { University of Vienna } \\
\text { / Technical Univer- } \\
\text { sity Vienna }\end{array}$ & $\begin{array}{l}\text { Business and Informatics } \\
\& \text { Science and Informatics }\end{array}$ & http://winf.univie.ac.at/ \\
\hline University Saarland & Law and Business & $\begin{array}{l}\text { http://www.uni- } \\
\text { saarland.de/de/studium/studienangebot/wirtschaftsinformatik/ }\end{array}$ \\
\hline University St. Gallen & Information Management & http://www.iwi.unisg.ch \\
\hline $\begin{array}{l}\text { London School of } \\
\text { Economics }\end{array}$ & Information Systems & $\underline{\text { http://is.1se.ac.uk/ }}$ \\
\hline $\begin{array}{l}\text { Loughborough Uni- } \\
\text { versity }\end{array}$ & Information Science & http://www.loughborough.ac.uk/departments/ls/ \\
\hline University Leeds & Computing & http://www.scs.leeds.ac.uk/ \\
\hline $\begin{array}{l}\text { University of Central } \\
\text { Lancashire }\end{array}$ & Business School & http://www.uclan.ac.uk/facs/lbs/depts/bim/index.htm \\
\hline $\begin{array}{l}\text { University of Liver- } \\
\text { pool }\end{array}$ & $\begin{array}{l}\text { Science \& Computer Sci- } \\
\text { ence }\end{array}$ & http://www.csc.liv.ac.uk/ \\
\hline $\begin{array}{l}\text { University of Man- } \\
\text { chester }\end{array}$ & $\begin{array}{l}\text { Computer Science \& } \\
\text { Business School }\end{array}$ & http://www.cs.man.ac.uk/ \\
\hline $\begin{array}{l}\text { University of Shef- } \\
\text { field }\end{array}$ & $\begin{array}{l}\text { Information Studies / } \\
\text { Computer Science }\end{array}$ & http://www.shef.ac.uk/uni/academic/I-M/is/home.html \\
\hline $\begin{array}{l}\text { University of Wales - } \\
\text { Cardiff }\end{array}$ & Business School & $\underline{\text { http://www.uwic.ac.uk/ubs }}$ \\
\hline $\begin{array}{l}\text { University College } \\
\text { Dublin }\end{array}$ & Business School & http://mis.ucd.ie/courses/IS_Programme \\
\hline $\begin{array}{l}\text { Dublin City Univer- } \\
\text { sity }\end{array}$ & $\begin{array}{l}\text { Computing in conjunction } \\
\text { with Business School }\end{array}$ & http://www.dcu.ie/prospective/ \\
\hline $\begin{array}{l}\text { University College } \\
\text { Cork }\end{array}$ & $\begin{array}{l}\text { Business Information } \\
\text { Systems }\end{array}$ & http://girtab2.ucc.ie/index.php/bis/mbs-bis/ \\
\hline
\end{tabular}




\section{Appendix B: List of Subjects Included in Programmes in the German-Speaking Regions}

Accounting and Financing

Accounting and Trust management

Analysis

Analysis, Planning and Design and Implementation of Business IS

Automotive Management

Business IT

Business Application with Internet

Business Communication Systems

Business Engineering

Business Information Processing

Business Languages

Business Organization

Business Processes

Business Statistics

Business Strategy and IS

$\mathrm{CH}$

Challenges in business informatics

Communication Engineering

Communication Systems

Communication Systems and Technology

Computer Supported Co-operative Work

Computing Architecture

Computing Architecture and System

Software

Corporate Controlling

Corporate Policy

Cultural Informatics

Data \& Knowledge Engineering

Data Management

Data Management (SQL)

Data Modelling
Data Structures

Data structures and programming algorithms

Data Warehousing

Database Systems

Database Technology

Decision Support Systems

Descriptive Statistics

Didactics in Business

E-Commerce / E-Business

Economics

Education science in Business

Energy Economy

Entrepreneurship

Environmental management

Financial statements and balances

Financing and Banking

Formal description of data and functional models

Formal Methods/Foundations of Informatics

Human resource management

Inductive Statistics

Industrial management

Information and Applications Systems

Information Engineering

Information Management

Information Systems (Informatics)

Information Systems and Software technique

Information Systems in Finance

Information Systems in Production Companies 
Insurance Management

Intelligent Systems / AI

International Management

Interorganisational Systems

IS Architecture

IT Security

Java Computing

Knowledge Management

Knowledge Representation and Knowledge based Systems

Legislation and Law

Linear Algebra

Logic

Logic Programming

Logistics

Management

Marketing

Methods and Tools of System development

Mobile Computing and Engineering

Modelling: Techniques and Methods

Multimedia

Multimedia Technologies

Network Computing and distributed systems

Numeric

Operations Management

Operations Research

Operations Systems

Organization

Philosophy

Planning and Decision theory

Planning

Politics
Practical Informatics

Probability and stochastic

Process and Communication Modelling

Programming and Programming Languages

Programming Approaches and Algorithmic

Programming Languages and Compiler

Project Management

Public Administration

Quantitative Methods

Service Industry and digital media

Service Management

Simulations

Sociology

Software Development

Software Engineering

Software oriented Informatics

Software technique

Statistical Data analysis and Data Mining

Statistics

Strategy

System Development and Database Systems

System development and IT-Management

System oriented Informatics

System platforms

System Programming

Taxation

Techniques of IT-consulting

Theoretical informatics

Web Engineering

Workflow Systems 


\section{Appendix C: List of Subjects Included in Programmes in the UK/Ireland}

Academic and Research Libraries

Advanced Database Technologies

Algorithm Design and Implementation

Analysis and design

Applications of Information Technology

Automating End User Systems

Biochemistry and Molecular Biology

Business Ethics

Business Information

Business Information Management Systems

Business Information Systems Techniques in Organizations

Business Simulation Modelling

Collaborative Internet Architectures and Systems

Communication, Visualization, and Interaction

Competitor intelligence

Computational Modelling

Computer and Network Architecture

Computer Architectures

Consumer health information

Culture and change management

Data Collection and Analysis

Database and 4th generation languages

Database Design

Database Structure and Design

Database Structure and Management

Decision Analysis and Decision Support Systems

Design and Authoring for the WWW

Design and Manufacture

Distributed Information Systems

E-Business

E-Business and E-Commerce

E-Business technologies

E-Commerce

Education
Educational Informatics

E-Government Information

Electronic Commerce

Electronic Publishing

E-Publishing: Design and production

E-Publishing: Marketing and business issues

Foundations for Object-Orientated Programming

Geography

HCI and Graphical Interfaces

Health

Healthcare Information

Human Computer Interaction and User Interface Design

Human Information Processing

Informatics and knowledge management systems

Information and knowledge management in the NHS

Information and Society

Information architecture

Information Management in Organizations

Information Needs Analysis

Information retrieval for knowledge management

Information Searching and Retrieval

Information Storage and Retrieval Research

Information Systems

Information Systems Analysis and Implementation

Information Systems and organization

Information Systems and the Information

Society

Information Systems Development Methodologies

Information Systems Management

Information Systems Modelling

Information Systems Project Management

Information Systems Strategy and e-Business 
Information Technology: Issues and Skills

Innovation and Technology Management

Intelligent information systems

Interaction design

Interactive System Design Methods

Interdisciplinary feasibility study

Internet and Intranet technology

Interorganisational Information Systems

Interpretations of Information

Introduction to Computer Systems

Introduction to Systems Thinking

IT Change Management

IT Policy and Development

Java and UML for Programmers

Java E-Commerce

Legal context of information and knowledge management

Library Services for Children and Young

People

Management II: Human Resource Management

Management of innovation and entrepreneurship

Management of the IS function

Management Science

Management techniques and people skills

Marketing for Information Professionals

Markup Languages for the WWW

Multi-Agent Systems

Multimedia

Multimedia and human-computer interaction

Network Architectures

Object Oriented Analysis and Design
Object Oriented Methods

Object-Oriented Programming in Java

Object-oriented systems

Organization, Management and Information Systems

Practical Computing

Principles of Information Retrieval

Principles of knowledge

Principles of Privacy and Data Protection

Principles of Research Design

Professional development skills

Professional Issues

Professional studies

Public Libraries

Records Management: Electronic Records

Records Management: Principles and Systems

Research Methodology in ILS

Research Methods and Dissertation Preparation

Research Skills and personal Development

Security in Information Systems for Organizations

Software Analysis and Design

Software Engineering

Strategic Management and Information Systems

Studies in Management

Systems Design in Context

Systems Development

Topics in IS (Global Consequences of IT, Knowledge, Organization and Technologies, E-Government) 


\section{Appendix D: Summary of Transferable Skills by Module}

\begin{tabular}{|c|c|c|c|c|c|c|c|}
\hline Module & 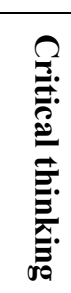 & 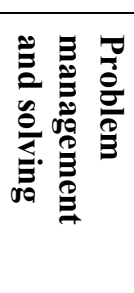 & 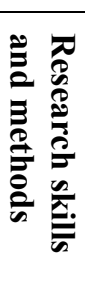 & 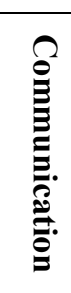 & 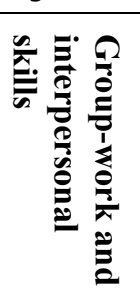 & 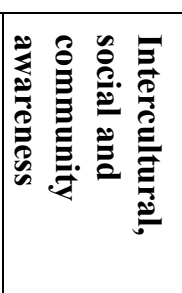 & 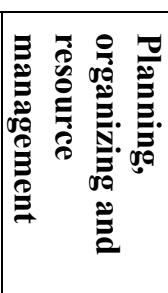 \\
\hline Research Skills/Seminar Topics & - & $\bigcirc$ & $\bullet$ & 1 & & & 1 \\
\hline Information System Architecture & $\bigcirc$ & $\bigcirc$ & & & & & \\
\hline Structural Science & $\bigcirc$ & 0 & & & & & 1 \\
\hline Business Process Management & $\bigcirc$ & 0 & 1 & & & & 1 \\
\hline Regulation in IS & $\bigcirc$ & $\bigcirc$ & & & & 1 & \\
\hline Business Studies & $\bigcirc$ & & & O & & 1 & 1 \\
\hline $\begin{array}{l}\text { Strategic Management of Infor- } \\
\text { mation Technology }\end{array}$ & $\bigcirc$ & 1 & & $\bullet$ & 1 & & $\bullet$ \\
\hline Supply Chain Management & $\bigcirc$ & 0 & & 1 & O & & 1 \\
\hline $\begin{array}{l}\text { Sectoral applications of Informa- } \\
\text { tion Systems }\end{array}$ & $\bigcirc$ & 1 & & & 1 & $\bigcirc$ & 1 \\
\hline Project Management & 1 & & $\bullet$ & 1 & 1 & $\bigcirc$ & 0 \\
\hline Managing Change & & 1 & & - & - & & \\
\hline $\begin{array}{l}\text { Managing and Working in an } \\
\text { Intercultural Environment }\end{array}$ & O & $\bigcirc$ & & - & $\bullet$ & 0 & \\
\hline Practicum & 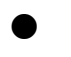 & 0 & 0 & 0 & $\bullet$ & $\bullet$ & - \\
\hline
\end{tabular}

$\begin{array}{lll}\text { Legend: } & - & \text { Considerable development } \\ & \text { - } & \text { Moderate development } \\ & \bigcirc & \text { Some development } \\ & & \text { Negligible development }\end{array}$

\section{Biography}

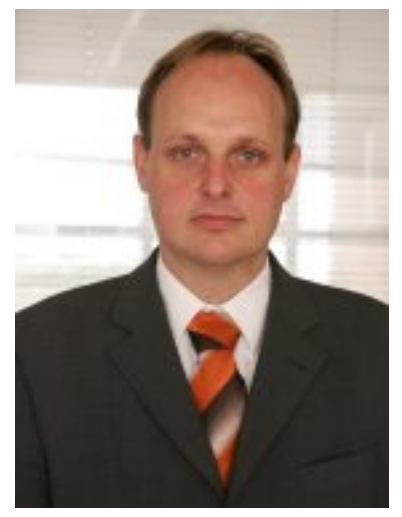

Dr. Markus Helfert is a lecturer in Information Systems at Dublin City University, Ireland and programme chair of the European M.Sc. in Business Informatics at Dublin City University. His research interests include Information Quality, Data Warehousing, Information System Architectures, Supply Chain Management and Business Informatics education. He holds a Doctor in business administration from the University of St. Gallen (Switzerland), a Master-Degree in business informatics from the University Mannheim (Germany) and a Bachelor of Science from Napier University, Edinburgh (UK-Scotland). 